\title{
Effectivity and Efficiency of Best Management Practices Based on a Survey and SWAPP Model of the Xiangxi River Basin
}

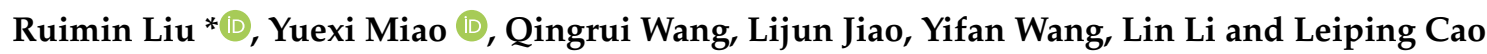 \\ State Key Laboratory of Water Environment Simulation, School of Environment, Beijing Normal University, \\ Beijing 100875, China; miaoyx0414@163.com (Y.M.); wangqr@mail.bnu.edu.cn (Q.W.); \\ lj.jiao@mail.bnu.edu.cn (L.J.); yf.wang@mail.bnu.edu.cn (Y.W.); lilin06@mail.bnu.edu.cn (L.L.); \\ caolp@mail.bnu.edu.cn (L.C.) \\ * Correspondence: liurm@bnu.edu.cn; Tel./Fax: +86-10-5880-0829
}

Citation: Liu, R.; Miao, Y.; Wang, Q.; Jiao, L.; Wang, Y.; Li, L.; Cao, L. Effectivity and Efficiency of Best Management Practices Based on a Survey and SWAPP Model of the Xiangxi River Basin. Water 2021, 13, 985. https://doi.org/10.3390/ w13070985

Academic Editor: Raghavan Srinivasan

Received: 10 March 2021

Accepted: 31 March 2021

Published: 3 April 2021

Publisher's Note: MDPI stays neutral with regard to jurisdictional claims in published maps and institutional affiliations.

Copyright: (c) 2021 by the authors. Licensee MDPI, Basel, Switzerland. This article is an open access article distributed under the terms and conditions of the Creative Commons Attribution (CC BY) license (https:/ / creativecommons.org/licenses/by/ $4.0 /)$.

\begin{abstract}
A questionnaire survey was conducted among farmers in the Xiangxi River Basin to investigate the local livestock situation and the farmers' understanding of and attitude towards pollution. The results showed that local farmers lacked environmental awareness and few livestock and poultry pollution treatment measures had been implemented. However, once farmers understood that livestock pollution would greatly influence their lives and interests, they would act to prevent Agricultural non-point source (ANPS) pollution. The farmers' education level and satisfaction with the environment were the main factors affecting their awareness regarding ANPS pollution. The "Comprehensive Environmental Optimization Tool SWAT-APEX Interface" model (SWAPP) was used to simulate the reduction of ANPS by different best management practices (BMPs) and the construction cost was calculated. The results showed that compound bedding and piping systems and ponds were the most effective and economic measures for reducing ANPS pollution. Spatially, implementing BMPs in the upstream region was better for improving water quality. The nitrate reduction rate in upstream sub-basins reached $90 \%$, which is 30\% larger than that in downstream sub-basins with combined bedding and piping systems. Combining the farmers' awareness of and engagement in livestock pollution with cost-effective BMPs can improve the BMPs' effectivity and efficiency.
\end{abstract}

Keywords: environmental awareness; agricultural non-point source pollution; best management practices; SWAT-APEX interface model; effectivity and efficiency analysis

\section{Introduction}

With the rapid socioeconomic development in recent decades, the issue of water pollution has become increasingly serious. Water pollution sources can be categorized as point source (PS) or non-point source (NPS) [1-3]. With the improvement of PS pollution control, NPS pollution has become more notable and difficult to control as it disperses easily, is difficult to detect, varies widely, and is hysteretic [4]. NPS pollution is primarily caused by local agricultural activities, such as the use of fertilizers and pesticides, livestock and poultry breeding, and rural household waste [5-8]. Agricultural NPS (ANPS) pollution has become a major cause of water quality degradation in many rivers [9-11] and identifying and controlling it has become key to improving the quality of the aquatic environment [12].

Among the various agricultural activities, livestock and poultry waste has become the largest ANPS pollutant in China as the total nitrogen (TN), total phosphorus (TP), and chemical oxygen demand (COD) of livestock and poultry waste accounted for 38\%, $56 \%$, and $96 \%$ of those of all agricultural sources, respectively [13-16]. Feces, sewage, and odor are the main pollutants produced by livestock and poultry farming $[13,17,18]$. In areas with a high livestock intensity, the spreading of manure on land could cause nitrogen and phosphorus to leach into water, causing eutrophication $[19,20]$. Furthermore, harmful gaseous substances, such as ammonia, produced by feces are a main source of 
air pollution, which not only affects people's health and delays the growth of livestock, but also increases the concentration of ammonia in the air, causing the amount of acid precipitation to increase by three to five times [21]. Therefore, preventing and controlling livestock pollution is imperative for protecting the aquatic environment in China.

Many measures of reducing livestock pollution have been developed in China and other countries. Best management practices (BMPs) are widely used to reduce NPS pollution, including livestock waste $[6,7,22]$. Research on practices for controlling and decreasing the negative impacts of ANPS pollution has been conducted for many decades, and the main practices include land-use change, reducing the use of pesticides and fertilizers, and terracing $[23,24]$. The implementation of these measures is affected by the local conditions, including economic, social, and environmental factors, and the preferences of farmers $[25,26]$, who are the main stakeholders in the implementation of BMPs. It is difficult to manage agricultural practices while excluding farmers and not considering whether they are willing to participate $[27,28]$. Therefore, the awareness and willingness of farmers to participate in pollution-reduction measures are also crucial issues in controlling agricultural pollution.

Prior to implementing BMPs, models should be used to simulate pollution loads and evaluate the effects of these practices [7]. Reliable environmental and economic models need to be integrated to select low-cost and highly effective environmental practices for agricultural watersheds $[29,30]$. The automated "Comprehensive Environmental Optimization Tool SWAT-APEX Interface Program" (SWAPP) was developed with funding from the U.S. Environmental Protection Agency [31]. The SWAPP model has been used to simulate the environmental impacts of different policies and management measures [32,33], and model has been widely applied to simulating livestock and poultry pollution and planning the maximum daily pollution loads of basins [33-36]. However, the SWAPP model does not consider the effectivity and efficiency of BMPs.

In this study, the Xiangxi River watershed, located in the Three Gorges Reservoir Region, was selected as the research area. A questionnaire survey was conducted to investigate the awareness and willingness of farmers to pay for agricultural environmental pollution-reduction measures, and the factors influencing their understanding were further analyzed. The economic and environmental benefits of several BMPs were then simulated using the SWAPP model. By combining the results of the questionnaire survey and SWAPP model, the effectivity and efficiency of different BMPs were discussed.

\section{Materials and Methods}

\subsection{Study Area}

The Xiangxi River watershed is located in the western part of Hubei Province, China $\left(30^{\circ} 57^{\prime}-31^{\circ} 34^{\prime} \mathrm{N}, 110^{\circ} 25^{\prime}-111^{\circ} 06^{\prime} \mathrm{E}\right)$. The area is approximately $3200 \mathrm{~km}^{2}$ and is the largest tributary of the Hubei Reservoir in the Three Gorges Reservoir Region (Figure 1). The watershed divides into three major tributaries, i.e., the Nanyang, Gufu, and Gaolan Rivers. The terrain in this area is complex, and the elevation varies between 110 and $3088 \mathrm{~m}$. The region experiences a humid subtropical continental monsoon climate. The average annual rainfall in the basin reaches $1100 \mathrm{~mm}$, and the average temperature is $15.6^{\circ} \mathrm{C}$. The high amount of rainfall and complex terrain make the region liable to NPS pollution.

The Xiangxi River watershed crosses Xingshan County from north to south. Xingshan County is a typical agricultural planting area with a high level of unmanaged chemical fertilizer and pesticide usage that pollutes groundwater and rivers and exacerbates eutrophication [37]. Agricultural planting, livestock farming, and domestic sewage are the main pollution sources in this region, and livestock farming (swine, cattle, and broiler) contributes the most to TN and TP discharge [38,39]. Furthermore, with the development of the livestock and poultry industry, the production of livestock and poultry manure is growing rapidly, while its utilization rate is low $[3,38]$. Therefore, the lost nutrients, such as nitrogen and phosphorus, enrich and pollute nearby water bodies. Thus, identifying 
the most appropriate and effective measures of controlling and decreasing pollution by livestock and poultry waste is urgent.

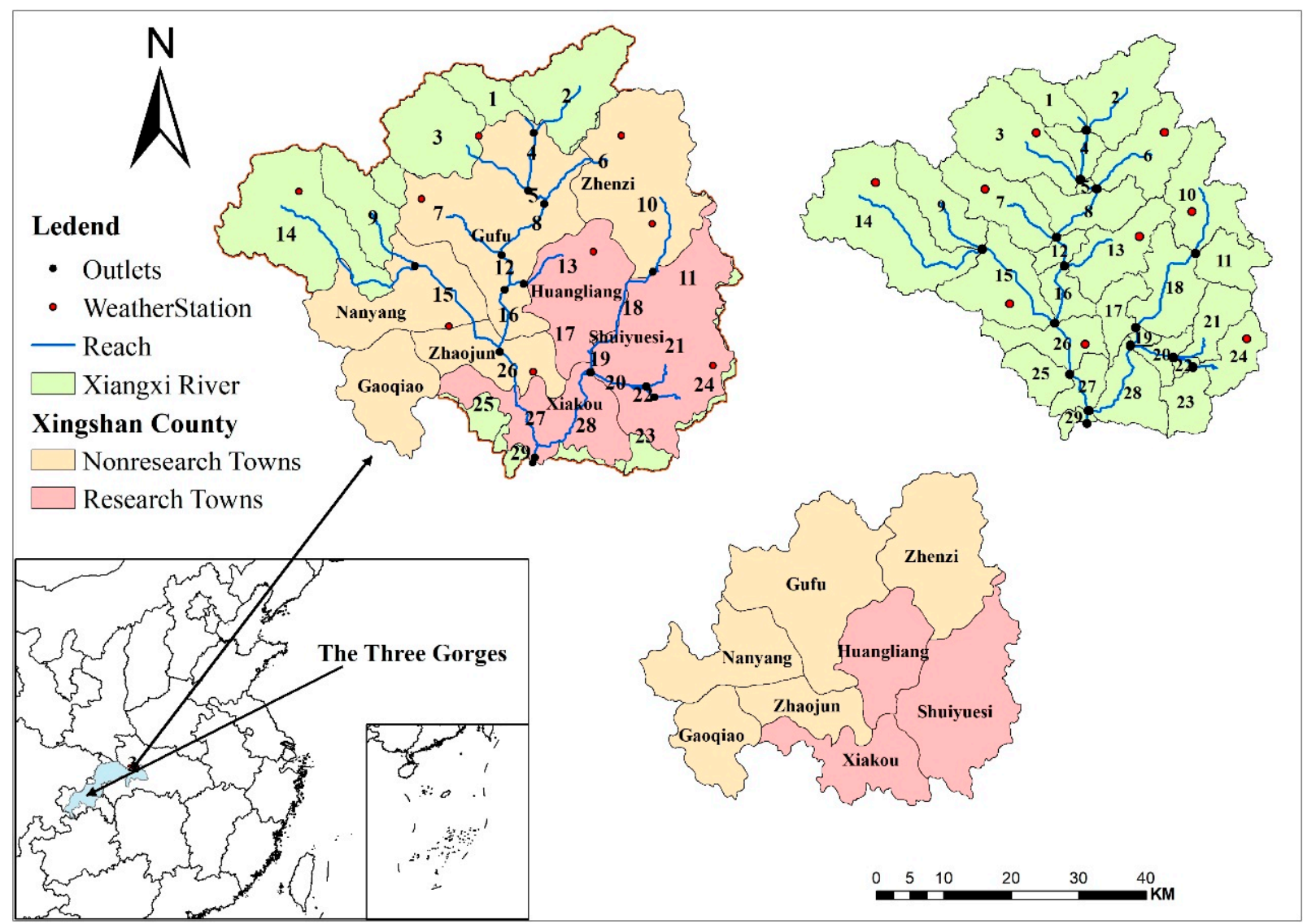

Figure 1. The map of study area.

\subsection{Questionnaire Survey}

In this study, livestock and poultry breeding in the Xiangxi River Basin, including eight towns and 109 administrative villages, was surveyed (Figure 1). The survey area was concentrated in Xingshan County. A questionnaire survey was conducted and supplemented by consultation and communication with local farmers. Basic information about the farmers included their age, sex, profession, and education level. All respondents were asked if they had ever reared livestock and poultry, and further information, such as the animal species, quantities, waste treatment methods, and the farmer's understanding of and attitude towards pollution, was collected from farmers who had raised livestock.

Farmers with an awareness of environmental problems may be more willing to participate in environmental prevention and management measures. A farmer's understanding of environmental problems can be regarded as a binary variable: has recognized $(=1)$ or has not recognized $(=0)$. Based on the survey, a binary logistic regression model was used to analyze the factors influencing the farmers' cognition. The form of the binary logistic model is as follows:

$$
\begin{gathered}
P=F(Z)=\frac{1}{1+e^{-Z}} \\
Z=b_{0}+b_{1} X_{1}+b_{2} X_{2}+\ldots+b_{n} X_{n}
\end{gathered}
$$

where $\mathrm{P}$ was the probability of the farmer's understanding of environmental problems, $X_{i}=(i=1,2, \ldots, n)$ is the independent variable (influencing factor), $b_{i}=(i=1,2, \ldots, n)$ is the regression coefficient of the $i$ th influencing factor, and $e$ is a random error term. $b_{0}$ and $b_{1}$ can be estimated following the maximum likelihood method. 
Cognition was used as the dependent variable when analyzing the binary logistic regression model. Meanwhile, the individual characteristics and environmental satisfaction of the farmers were selected as the independent variables (Table 1).

Table 1. Variable descriptive statistics in Binary Logistic regression model.

\begin{tabular}{|c|c|c|c|}
\hline Variables & Description & Mean Value & Standard Deviation \\
\hline \multicolumn{4}{|l|}{ dependent variable } \\
\hline farmers cognition & $\begin{array}{c}\text { have recognized }(=1) \\
\text { have not recognized }(=0)\end{array}$ & 0.58 & 0.497 \\
\hline \multicolumn{4}{|l|}{ independent variables } \\
\hline Sex & male $(=1)$; female $(=2)$ & 1.77 & 0.425 \\
\hline Age & $24 \sim 83$ & 52.18 & 12.463 \\
\hline education & $\begin{array}{c}\text { Uneducated }(=1) ; \\
\text { primary school }(=2) ; \\
\text { middle school }(=3) ; \\
\text { high school }(=4) ; \\
\text { College degree or above }(=5)\end{array}$ & 2.58 & 1.112 \\
\hline work & $\begin{array}{c}\text { Farmer }(=1) ; \\
\text { worker }(=2) ; \\
\text { self-employed }(=3) ; \\
\text { others }(=4)\end{array}$ & 1.98 & 1.18 \\
\hline environmental satisfaction & $\begin{array}{c}\text { rather dissatisfied }(=1) \\
\text { dissatisfied }(=2) \\
\text { normal }(=3) ; \\
\text { satisfied }(=4) ; \\
\text { Rather satisfied }(=5)\end{array}$ & 3.31 & 0.843 \\
\hline
\end{tabular}

\subsection{SWAPP Model}

The SWAPP model was used to analyze the environmental effects of different BMPs. SWAPP modeling systems incorporate the following environmental models: (1) Soil and Water Assessment Tool (SWAT) and (2) Agricultural Policy/Environmental Extender (APEX). SWAPP converts SWAT files to-and-from APEX format and simultaneously simulates SWAT and APEX. This arrangement of the SWAT and APEX models allows us to simulate scenarios, such as filter strips, at the field-level using APEX, which is not feasible in SWAT [32].

The Soil and Water Assessment Tool (SWAT) is a semi-distributed, process-based hydrological model used for continuous simulations of various processes that was developed by the United States Department of Agriculture Agricultural Research Service [40]. SWAT can be used to predict the impacts of management on water, sediment, and agricultural chemical yields in large, ungauged watersheds on a daily basis $[40,41]$. The water balance is the basis of the SWAT model, on which pollutant simulation is based [42]. The water balance is calculated as follows:

$$
S W_{t}=S W_{0}+\sum_{i=1}^{t}\left(R_{\text {day }}-Q_{\text {surf }}-E_{a}-W_{\text {seep }}-Q_{g w}\right)
$$

where $S W_{t}$ is the final soil moisture content, $S W_{0}$ is the initial soil moisture content, $R_{\text {day }}$ is the rainfall, $Q_{\text {surf }}$ is the surface runoff, $E_{a}$ is the evapotranspiration, $W_{\text {seep }}$ is the water transferred from the soil profile into the gas zone, and $Q_{g w}$ is the return streamflow on day $i$.

APEX is a tool for managing whole farms or small watersheds to obtain sustainable production efficiency and maintain environmental quality [43]. APEX operates on a daily time step and is capable of performing long term simulations at the whole farm or small 
watershed level [44]. Effects of terrace systems, grass waterways, strip cropping, buffer strips/vegetated filter strips, crop rotations, plant competition, plant burning, grazing patterns of multiple herds, fertilizer, irrigation, liming, furrow diking, drainage systems, and manure management (feed yards and dairies with or without lagoons) can be simulated and assessed $[45,46]$.

Several alternative BMPs were selected to assess their effectiveness for reducing nutrient and sediment losses within the SWAPP model (Table 2). The main function of bedding and pipes was to store water when there was too much rain, or transport excess underground water through pre-laid pipes. The bedding and piping systems (bedding and piping-no ditches improvement (BP-ND), bedding and piping-ditches expansion and reservoir system (BP-DER), bedding and piping-two stage ditches system (BP-TSD), and bedding and piping-tailwater irrigation (BP-TWI)) can reduce the accumulation of livestock and poultry manure and discharge the manure-polluted water [47]. The vegetation filter belt (FB) is actually a strip formed by densely planted plants or crops, which is mainly used to intercept the runoff from the source of pollution and filter out the pollutants [48]. The filter belt can also increase regional infiltration and reduce surface runoff and non-particle pollutants. Therefore, it can effectively reduce the levels of nutrients in manure to minimize water pollution [49]. Land leveling (LL) can change the distribution of nitrogen and phosphorus in the manure and other pollutants and reduce soil erosion along a slope. Meanwhile, dikes mitigate flood disasters and protect farmland during the flood season [50]. Pond construction is also an effective method of reducing non-point source pollution that can effectively prevent runoff, sediment, and nutrients from entering a river or field.

To compare the pollution abatement by different environmental pollution control measures, the flow rate and production of sediment, organic nitrogen (ORGN), organic phosphorus (ORGP), nitrate $\left(\mathrm{NO}_{3}{ }^{-}\right)$, phosphate $\left(\mathrm{PO}_{4}{ }^{3-}\right)$, $\mathrm{TN}$, and TP in the entire basin were statistically analyzed.

Table 2. Scenarios management setting in SWAPP.

\begin{tabular}{|c|c|c|}
\hline Scenarios & & Specific Measures \\
\hline FB & \multicolumn{2}{|c|}{ Select vegetation type, planting width and removal rate } \\
\hline LL & \multicolumn{2}{|c|}{ Set the slope reduction percentage } \\
\hline $\mathrm{BP}-\mathrm{NDI}$ & \multirow{4}{*}{ Lay straws and pipeline } & Set bedding and pipe width \\
\hline BP-DER & & Set bedding, pipe width and reservoir area \\
\hline BP-TWI & & $\begin{array}{l}\text { Set bedding, pipe width and reservoir area; } \\
\text { add automatic irrigation }\end{array}$ \\
\hline BP-TSD & & Set bedding and pipe width \\
\hline Permanent dikes & & No special setting \\
\hline Ponds & \multicolumn{2}{|c|}{ Set the ratio affected by the pond } \\
\hline
\end{tabular}

The construction costs of BMPs were estimated using data summarized from studies conducted in China and other countries [7,51-54]. The BMPs database website (http:/ /ww w.bmpdatabase.org, accessed on 31 March 2021) was combined with the Standard for Land Consolidation Engineering in Hubei Province to account costs.

Plastic pipes with an inner diameter of $0.15 \mathrm{~m}$ were selected for the pipeline system, and they were placed at a depth of $1-2 \mathrm{~m}$ with a spacing of $15 \mathrm{~m}$. The two-stage ditches piping system combined pipelines and ditches with a depth of $1.5 \mathrm{~m}$, width of $8 \mathrm{~m}$, and spacing of $50 \mathrm{~m}$. The ditches expansion and reservoir system included reservoirs with a depth of $3 \mathrm{~m}$ and width of $20 \mathrm{~m}$ to drain water based on a pipeline and ditch system. Ponds had a depth of 1-3 m, while dams required high construction costs, but had no specific data. 


\subsection{Data Collection and Model Setup}

The data used in the SWAPP model included land use, soil, meteorological, hydrologic, water quality, and local livestock data. The land-use data for 2010 were obtained from a Landsat 5 TM satellite image and interpreted by the Environment for Visualizing Images (ENVI) at a resolution of $30 \mathrm{~m}$. The soil maps ( $30 \mathrm{~m}$ resolution) were obtained from the Institute of Geography, Chinese Academy of Sciences. The soil properties were collected from the Chinese soil database and local surveys (National Soil Survey Office, 1998). The sub-watersheds were delineated using the second version of the Advanced Spaceborne Thermal Emission and Reflection Radiometer Global Digital Elevation Model (ASTER GDEM2), which was released in 2011. Daily meteorological data from 2000 to 2014 recorded at nine weather station were provided by the China Meteorological Administration, and included precipitation, temperature, solar radiation, wind speed, and relative humidity. Daily streamflow and water quality data from 2002 to 2011 were obtained from the Yangtze Water Resources committee. Livestock farming and agriculture data were obtained from statistical and field survey data. Finally, the livestock and poultry breeding numbers from 2000 to 2015 were obtained from The Statistical Yearbook of Xingshan, 2000-2015.

Based on the collected data, the pollution characteristics of livestock and poultry were estimated, and Huangliang, Shuiyuesi, and Xiakou produced the most livestock pollutants [39]. The SWAT model was then used to delineate watersheds and analyze ANPS with a new manure database. Among the 27 sub-watersheds delineated within the entire watershed, sub-basins 12,16, 11, 19, 20,21, 22, 23, 24, 25, 26, and 27, which fell within the administrative boundaries of Huangliang, Shuiyuesi, and Xiakou, were selected as the research areas (Figure 1). Only land-use types involving farming, such as cultivated land, woodland, grassland, and paddy fields, were simulated by APEX. Based on the application of manure in different sub-basins, different management measures were applied. The pollutant load at the outlet of each basin was an annual average calculated from 14 years of data.

\section{Results and Discussion}

\subsection{Characteristics of Respondents}

Ninety valid questionnaires were obtained. The demographic characteristics of the survey showed that, among all the respondents, the number of females was nearly four times higher than the number of males (Table 3). Most respondents had been reeducated to primary school level (37\%), and far fewer had been to junior college (4\%). The respondents were mostly farmers, or local self-employed, aged between 30 and 70, with considerable farming experience. Among the sampled farmers, almost 50\% raised some type of livestock or poultry.

The most common livestock and poultry feces treatment method in Xingshan County was rinsing and dry collection, accounting for $91 \%$ of all treatment methods (Figure 2a). Only a small number of farmers chose to let livestock and poultry live in the mountains without centralized manure treatment measures. Furthermore, most of the sewage generated by manure rinsing underwent no emission-reduction measures and was directly discharged into nearby canals that flow into the main river channel, posing a great threat to the environment. Most farmers directly returned the collected feces to their fields as organic fertilizer after undergoing natural fermentation, and only $23 \%$ of the respondents had a biogas digester (Figure 2 b). The majority ( $64 \%$ ) of the farmers buried sick and dead livestock and poultry (Figure 2c), while $24 \%$ of the farmers did not have any treatment measures for dead livestock and poultry-they directly threw dead animals into the mountain or nearby drainage ditches, spreading disease and increasing environmental pollution. Very few farmers had implemented incineration treatment. 
Table 3. Demographic characteristic of surveyed respondents.

\begin{tabular}{ccc}
\hline Variable & Options of Variable & Percentage (\%) \\
\hline \multirow{2}{*}{ Sex } & male & 23 \\
& female & 77 \\
\hline \multirow{2}{*}{ Age } & below 30 & 6 \\
& $31-50$ & 38 \\
& $51-70$ & 52 \\
Profession & over 70 & 4 \\
& worker & 6 \\
& farmer & 56 \\
& Self-employed & 24 \\
& others & 14 \\
\hline \multirow{2}{*}{ Education } & no education & 17 \\
& primary school & 37 \\
& middle school & 23 \\
& high school & 19 \\
& college degree or more & 4 \\
\hline
\end{tabular}

The results showed that $58 \%$ of the surveyed farmers were willing to pay for pollution control measures for livestock and poultry breeding (Figure 2e). Over half of the farmers were willing to accept a fee of 10-20 yuan/month for controlling livestock breeding pollution. Another 33\% of the farmers surveyed said they were unwilling to pay for the prevention and control of pollution from livestock and poultry. A small number of farmers $(9 \%)$ said that they could be willing to pay, but the specific amount would be determined by the actual situation and the measures to be taken.

The level of environmental awareness and the understanding of environmental conservation in local communities is generally low. With urbanization and economic development, a growing number of rural people are working in cities. However, in the rural areas of China, women still frequently remain at home [55]. These women are typically poorly educated but play a significant role in the daily life and agricultural activities. Furthermore, they are more concerned with maintaining their livelihoods than environmental problems [56]. Some farmers may also be unaware of the damage caused by livestock and poultry pollution to the environment and impacts on agricultural production [28]. Furthermore, environmental protection measures in rural areas are inadequate. The environmental impact of livestock breeding has not attracted sufficient attention from local policy-making and environmental protection departments, and the prevention and control of livestock and poultry pollution have not been suitably publicized [57]. All these factors have contributed to the severe environmental problems in rural areas.

Feces treatment

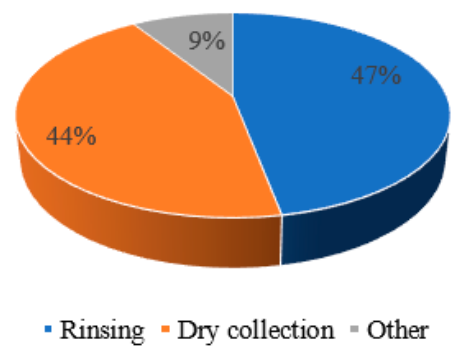

(a)

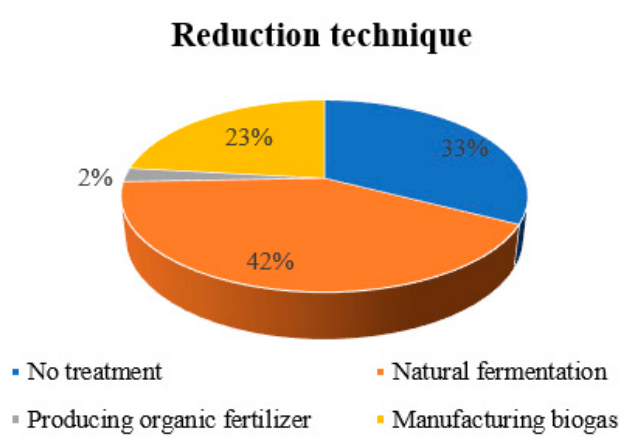

(b)

Figure 2. Cont. 


\section{Treatment of dead livestock and poultry}

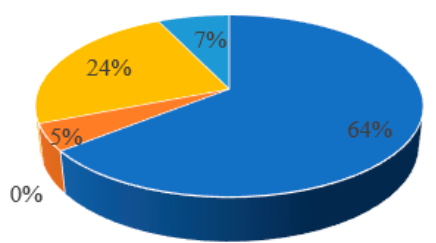

- Incineration " Landfill disposal " Harmless treatment

- No treatment $\quad$ - Don't know

\section{Understanding of livestock pollution control}

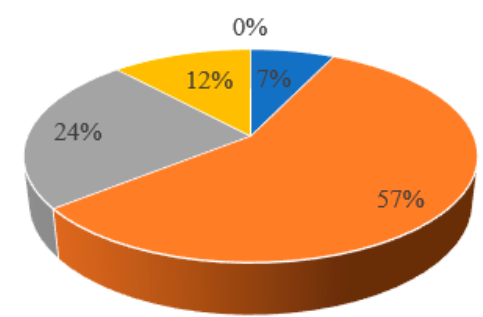

- Don't know = Too little = Just right = Know well " Too much

(c)

(d)

\section{The fees willing to pay for livestock}

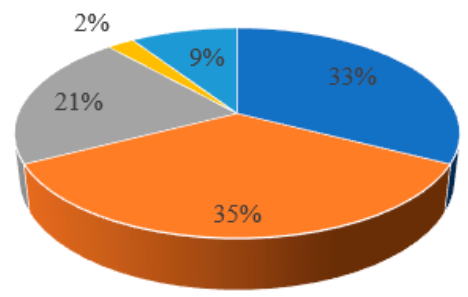

$\begin{array}{ll}\text { Plot Area } & \text { " below 20 yuan } \\ \text { unwmrmig pay } & \text { " depend on matter of fact }\end{array}$

(e)

Figure 2. Questionnaire statistical results;(a) The main processing method for excrements. (b) Fecal reduction technique. (c) Processing for the dead livestock. (d) How familiar the farmers with livestock control. (e) The fees willing to pay for livestock.

Over half (64\%) of the surveyed households did not know about the prevention and control of livestock and poultry pollution (Figure 2d). Those who knew or had heard a little about it accounted for $36 \%$ of the surveyed population, while none of the respondents understood pollution prevention and control very well. The majority of the surveyed farmers said that the village that they lived in did not have clear regulations regarding pollution from livestock and poultry breeding, and almost all of the surveyed farmers reported that they had not seen the villages or communities publicize the control of pollution from livestock and poultry farming.

The awareness of farmers towards environmental pollution is gradually increasing. Regardless of the cost, over half of the surveyed farmers were willing to pay a fee for pollution prevention and control, even if they did not know what measures would be taken or how they could benefit from the adoption of BMPs. Farmers tended to accept off-farm pollution reduction practices and were particularly opposed to practices that occupied cultivated lands or changed the conventional planting methods [23]. However, the farmers were unaware of how severely livestock pollution affects their benefits [58]. Once they understood that livestock pollution influences their livelihoods and interests, most farmers were willing to pay a fee for pollution prevention and control, including on-farm and off-farm measures [27]. 


\subsection{Factors Influencing Farmers' Awareness of ANPS Pollution}

The respondents' awareness of NPS pollution is an important factor affecting their willingness to participate in pollution prevention and control activities. The results of the binary logistic regression model showed that two variables significantly affected the farmers' understanding of NPS pollution, i.e., respondents' education level and their satisfaction with the environment. However, the gender and age of the respondents did not significantly influence their understanding of pollution (Table 4). Farmers with a high educational level and low environmental satisfaction had a greater awareness of environmental pollution.

Table 4. Estimation results of factors influencing farmers' cognition to environmental pollution.

\begin{tabular}{ccccccc}
\hline & B & S.E. & Wals & df & Sig. & Exp(B) \\
\hline Education & 0.437 & 0.218 & 4.009 & 1 & 0.045 & 1.549 \\
Satisfaction & -1.245 & 0.353 & 12.454 & 1 & 0.000 & 0.288 \\
Constant & 3.435 & 1.343 & 6.547 & 1 & 0.011 & 31.038 \\
\hline
\end{tabular}

According to the survey, $50 \%$ of the respondents were satisfied with their living environment, $17 \%$ said they were not satisfied, and some said they were extremely dissatisfied. Among the farmers satisfied with their living conditions, only $39 \%$ held the opinion that there were environmental problems. However, up to $71 \%$ of farmers with an education level of high school or above had noticed the environmental problems. Furthermore, $60 \%$ had realized environmental pollution and were willing to pay for and participate in pollution control. Farmers regarded livestock and poultry farming and the decrease of forest vegetation due to sheep herding as the main causes of environmental problems, according to the survey.

The lack of awareness of the environmental impacts caused by livestock breeding and the insufficiency of relevant environmental protection measures were the major problems in local rural areas. Promotion from the government may be a significant incentive affecting the use of BMPs [23]. However, determining methods of improving the agricultural environment is not only interesting to government agencies, but also to the individual stakeholders involved [28]. Improving the farmers overall understanding of environmental protection will improve their participation in conducting BMPs and is important for resolving NPS pollution [59]. The government or local organizations could provide farmers with more education, training, and other assistance, such as agricultural extension services, to help them adopt BMPs [27]. Consistent publicity to arouse public interest in the issue of environmental protection is another method of raising the environmental awareness of farmers [60].

\subsection{Environmental Benefits and Economic Analysis of BMPs}

Based on the SWAT model, several related parameters were calibrated, and the results were validated. The $\mathrm{R}^{2}$ and NSE values for flow were 0.76 and 0.71 , and those for phosphorus were 0.77 and 0.65 , respectively [39]. The environmental benefits of several BMPs were then analyzed with the calibrated and validated SWAT model.

The amount of pollutants produced throughout the basin by applying each measure was below the simulated baseline (no BMPs were taken), indicating that pollution reduction measures were necessary for controlling NPS pollution (Figure 3). Various BMPs had little impact on the river's flow during the simulation period, as the river flow value almost did not change (fluctuations were less than 0.01 ) before and after applying the measures. Among all BMPs, the application of a combined piping system and ponds significantly reduced sediment and nitrogen, and $\mathrm{NO}_{3}{ }^{-}$exhibited the highest reduction rate (above $40 \%$ ). However, the phosphorus removal effect was not notable. BP-TWI, a combined piping system, exhibited the highest reduction rates, reducing $\mathrm{NO}_{3}{ }^{-}$by $40.6 \%$, sediment by $6.2 \%$, and TN by $5.6 \%$. However, the removal of all pollutants by FB, LL, BP-ND, and 
dikes was not remarkable, and the reduction rates were all below 3\%. BP-ND had the lowest effect on pollutant reduction, as the reduction rates were all below $0.03 \%$.

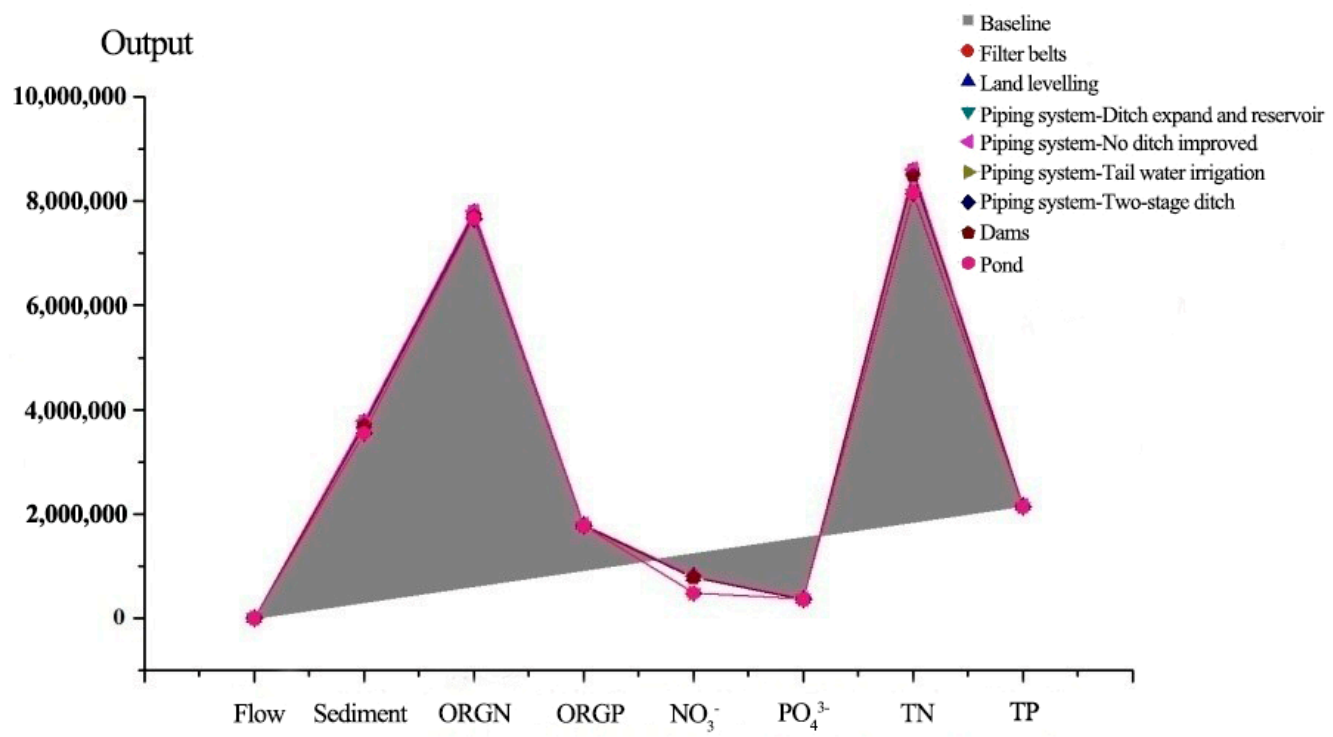

Figure 3. The comparison between the baseline and the scenarios. (Flow unit: $\mathrm{kg} / \mathrm{m}^{3}$; Sediment unit: t; Pollutants unit: kg).

Spatially, although the reduction effects of the combined piping systems were better than those of most single measures in each watershed, the reduction rate achieved by each BMP in the upstream areas was generally higher than that achieved in the downstream areas (Figure 4). Among all sub-basins, the reduction rates of almost all pollutants by most measures were highest in upstream sub-basin 16 . However, each measure did not have a good effect on reducing pollutants at the outlet of sub-basin 27 . In the three combined systems (BP-TWI, BP-DER, and BP-TSD), the reduction rate of $\mathrm{NO}_{3}{ }^{-}$reached approximately $90 \%$ in the upstream sub-basins, and the $\mathrm{NO}_{3}{ }^{-}$and sediment reduction percentages were up to $30 \%$ higher than those in the downstream sub-basins. However, the reduction rates achieved by single measures in the upstream regions were not as high as those of the combined measures, and the differences in the reduction rates between the upstream and downstream regions were not notable (ranging from $0.02 \%$ to $20 \%$ ).

Economically, ponds were the least expensive measure among the eight BMPs (Table 5). The bedding and pipeline systems were also economical practices, and the cost of BP-TSD was the lowest among the piping systems (minimum of 90 yuan acre). Furthermore, the combined piping systems were cheaper than pipe laying alone. However, the prices of other single measures, such as filter belts and LL, are relatively high-the cost of LL is almost 3000 yuan acre. The economic benefits of piping systems are also remarkable as they reduce land occupation, improve soil conditions, and increase crop yields [61].

Considering the construction costs and environmental benefits of the BMPs, the combined BMPs (BP-DER and BP-TWI) and ponds were cost-effective measures for reducing NPS pollution in the study area. Combining ditches, reservoirs, and tailwater irrigation with ponds in a piping system may be an effective method of achieving the desired benefits and achieving high environmental effectiveness at a low cost. 


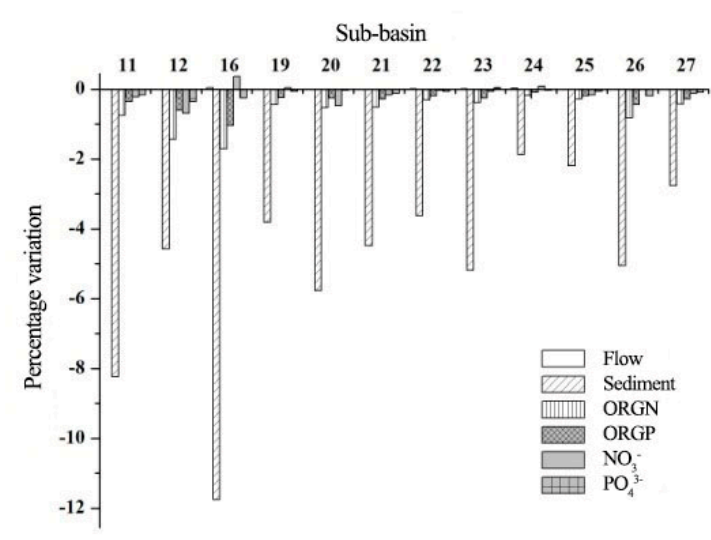

(a)

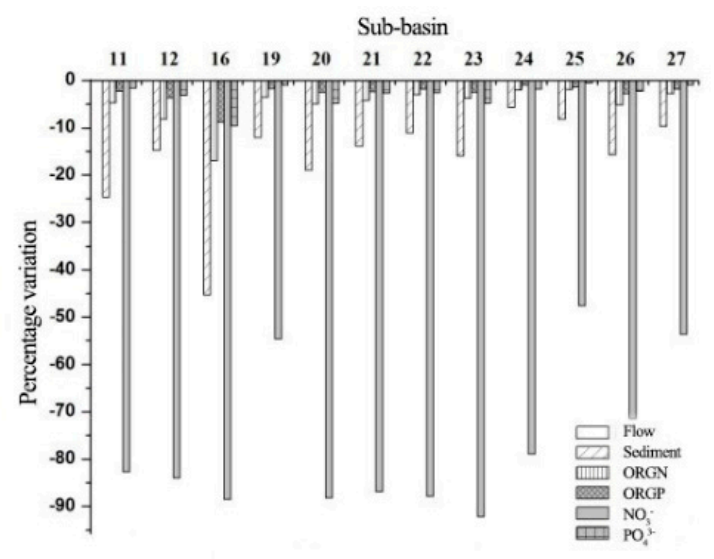

(c)

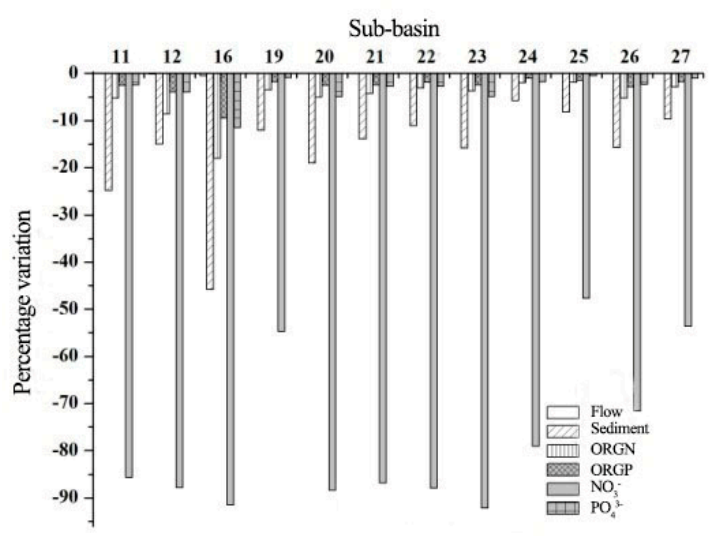

(e)

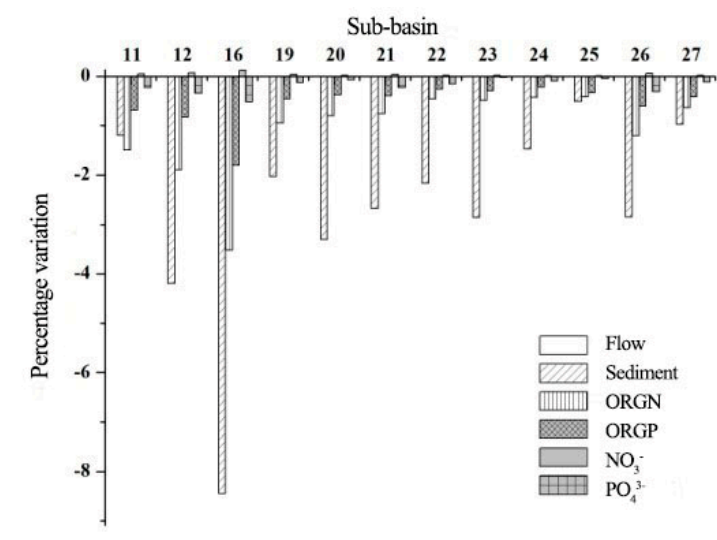

(b)

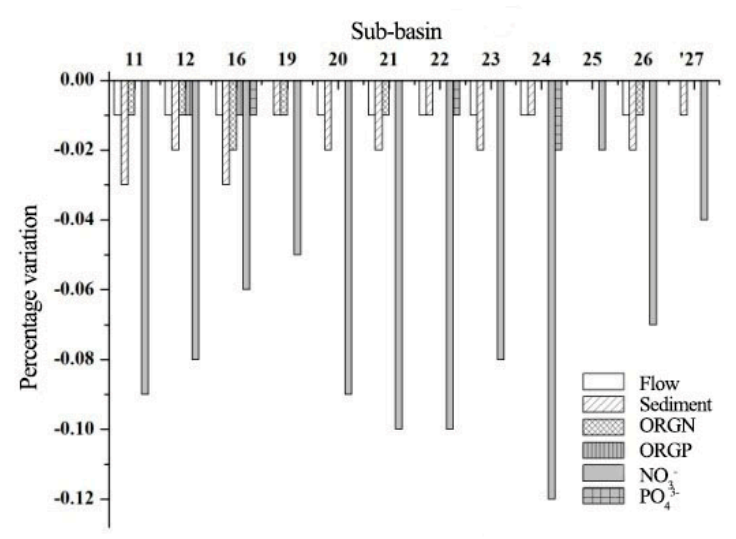

(d)

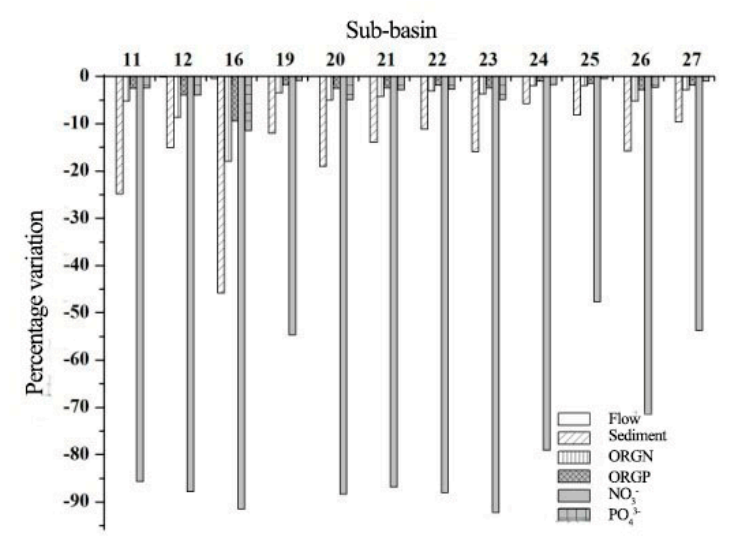

(f)

Figure 4. Cont. 


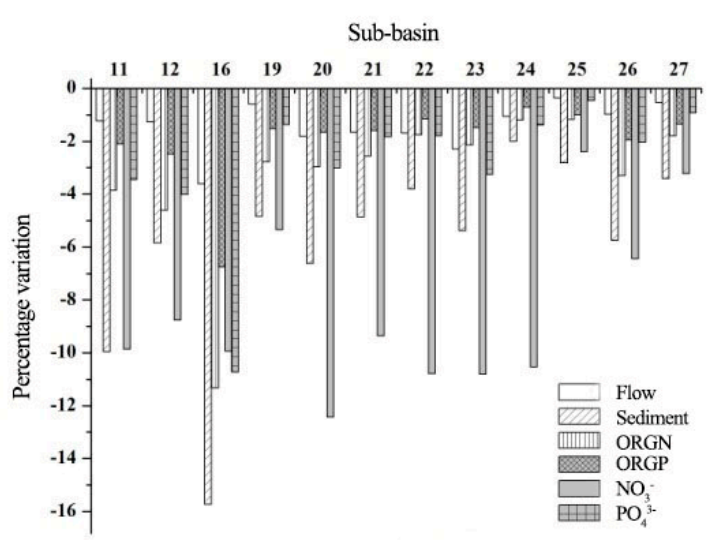

(g)

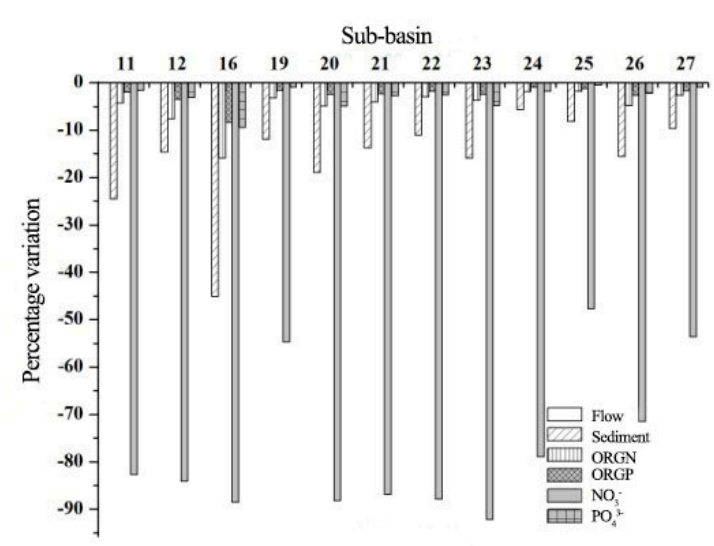

(h)

Figure 4. Pollutants percentage changes between the baseline and the scenarios in different subbasins; (a) Filter belt. (b) Land levelling. (c) Bedding and piping system-ditch expansion and reservoir. (d) Bedding and piping system-no ditch improved. (e) Bedding and piping system-tail water irrigation. (f) Bedding and piping system-two stage ditches. (g) Permanent dams. (h) Ponds.

Table 5. Construction costs of BMPs.

\begin{tabular}{cc}
\hline Measures & $\begin{array}{c}\text { Construction Cost } \\
\text { (Yuan Acre) }\end{array}$ \\
FT & $607-1214$ \\
LL & $1278-2904$ \\
BP-DER & $140-370$ \\
BP-NDI & $121-387$ \\
BP-TWI & $145-465$ \\
BP-TSD & $90-290$ \\
Permanent dikes & - \\
Ponds & $80-140$ \\
\hline
\end{tabular}

\subsection{Effectivity and Efficiency of BMPs}

The simulated BMPs exhibited good nitrogen removal. The reduction of nitrogen $(\mathrm{N})$ loads by BMPs such as tillage management was higher than the reduction of phosphorus $(\mathrm{P})$ loads $[7,62]$. Furthermore, the tillage system did not appear to influence the TP content [63]. This may be because the nutrients ( $\mathrm{N}$ and $\mathrm{P}$ ) in animal manures were stored and recycled into farmlands in improved ditches, tailwater irrigation, and pond systems. Nitrate easily absorbs and accumulates in crops and vegetables in reuse systems [64,65], while the availability of phosphorous in the acidic soils of the Xiangxi River watershed is poor. Reusing rural domestic sewage to irrigate farmlands can improve the crop yield while efficiently removing pollutants [66]. Using the nutrients in waste by combining water management with fertilization in agriculture is a useful, efficient, and sustainable method of reducing pollution.

When assessing the practical application of pollution-reduction measures, the maintenance costs, landowner opportunity costs (compensation for returning farmlands to forests or the construction of BMPs), agricultural production, and ecological effects must also be considered to quantify the long-term benefits of BMPs implemented in the watershed [7]. The cost-effectiveness and cost-benefit ratios of BMPs for reducing pollution were calculated to further ensure economic returns for five to ten years after their implementation $[7,29]$. 
The effectivity and efficiency of BMPs are closely related to the spatial allocation. The efficiency of a BMP is likely to vary between different locations within a watershed $[67,68]$. Pollutants tend to accumulate downstream due to the topography and erosion by rainfall runoff [69]. Therefore, it is beneficial to consider the upstream-downstream linkages during the construction of BMPs and other infrastructure to ensure that the pollution-reduction measures perform well [70]. Good catchment management practices for protecting the ecological environment in the upstream region can provide with downstream communities high-quality water resources, such as clean and sustainable water [71]. Spatially optimizing BMPs is an effective method of selecting and allocating BMPs for watershed management [39,72]. Optimizing the selection and placement of BMPs was found to triple their cost-effectiveness in comparison to targeting strategies for ensuring the same level of protection based on the maximum monthly sediment, phosphorus, and nitrogen loads [67].

The inclination of farmers towards accepting BMPs also needs to be considered. As they are important participants in agricultural activities, the involvement of farmers directly affects the implementation effectivity and efficiency of BMPs [73]. The more knowledge farmers have about NPS pollution and the better their awareness of environmental pollution, the easier it is for farmers to facilitate the implementation of BMPs [74]. Implementing BMPs can improve the environment and also increase the long-term local economic benefits $[7,75,76]$. The peer effect would also influence farmers' choices, as BMPs are more likely to be adopted by farmers whose peer networks support and promote such practices [77]. Furthermore, BMPs that are more familiar, simple, and can be easily integrated into existing management practices are more likely to be adopted [59].

The selection and implementation of BMPs is critical to a regional environment [78]. Suitability for local conditions and general acceptability are issues need to be considered [27]. Decision makers need to coordinate multi-interest among the stakeholders and emphasize stakeholder consultation to meet local stakeholders' needs [79]. It is advisable to provide more space for public participation in addressing environmental issues [80]. Cash incentives such as payments or subsidies will motivate farmers to adopt BMPs. In addition to education and publicity, attention should also be paid to technical support and extension services, such as guidance and assistance, to give farmers sufficient knowledge and technical skills to apply designed measures [81].

\section{Conclusions}

In Xingshan County, farmers' environmental awareness and understanding of environmental conservation are generally low. Most of the surveyed rural households had little understanding of the prevention of livestock pollution, and the propaganda about public knowledge regarding the control of livestock breeding pollution was inadequate. However, farmers are gradually becoming aware of environmental pollution. Most villagers were willing to bear the corresponding costs for minimizing livestock pollution within an affordable range. The farmers' education level and satisfaction with the environment significantly affected their awareness of ANPS pollution, according to the results of the Binary Logistic model. Farmers with a high educational level and low environmental satisfaction were better aware of environmental pollution. Therefore, financial incentives or economic subsidies, intensive education efforts, and consistent publicity also need to be established to improve the farmers' overall environmental protection consciousness to further encourage their involvement in implementing BMPs.

The environmental benefits of BMPs were analyzed with a calibrated and validated SWAT model. Among all selected BMPs, the application of combined piping systems and ponds significantly reduced the levels of pollutants, with $\mathrm{NO}_{3}{ }^{-}$reduction rate exceeding $40 \%$ throughout the basin. In contrast, the effect on phosphorus removal was not notable. The construction costs of combined piping systems and ponds were also relatively low. Upon considering the construction costs and environmental benefits of the BMPs, the combined BMPs (BP-DER and BP-TWI) and ponds were the most cost-effective measures for reducing non-point source pollution in the study area. Spatially, the reduction effect 
was more notable in the upstream area than the downstream area. The reduction rate of $\mathrm{NO}_{3}{ }^{-}$by three combined systems (BP-TWI, BP-DER, and BP-TSD) reached approximately $90 \%$ in upstream sub-basins, which is $30 \%$ higher than that in downstream areas. However, the reductions achieved by single measures in the upstream area were not as significant as those achieved by the combined measures, and the differences in the reduction rates between the upstream and downstream were not notable.

Ensuring and improving the effectivity and efficiency of BMPs is vital for reducing ANPS pollution. Combining cost-effective BMPs with the local situation can improve the environmental situation. As farmers are the main stakeholders of BMPs and should be involved, the factors influencing their choices and determining approaches to encourage their participation must be explored. Under governmental impetus, improving farmers' awareness of environmental protection and further encouraging them to adopt cost-effective BMPs can achieve desirable benefits.

Author Contributions: Conceptualization, R.L. and Y.M.; methodology, R.L.; Q.W. and Y.M.; software, Q.W.; validation, R.L.; Q.W. and Y.M.; investigation, Y.M.; L.J.; Y.W.; Q.W.; L.L. and L.C.; writing—original draft preparation, Y.M.; writing—review and editing, R.L.; visualization, Y.M.; supervision, R.L.; project administration, R.L.; funding acquisition, R.L. All authors have read and agreed to the published version of the manuscript.

Funding: This study was funded by the National Natural Science Foundation of China (41571486), the National Key Research and Development Program of China (2017YFA0605001) and the Interdisciplinary Research Funds of Beijing Normal University.

Institutional Review Board Statement: Not applicable.

Informed Consent Statement: Not applicable.

Data Availability Statement: No additional data are available. All data generated or analysed during this study are included in this published article.

Acknowledgments: The authors thank the editors and anonymous reviewers for their valuable comments and suggestions.

Conflicts of Interest: The authors declare no conflict of interest.

\section{References}

1. Edwards, A.C.; Withers, P.J.A. Transport and delivery of suspended solids, nitrogen and phosphorus from various sources to freshwaters in the UK. J. Hydrol. 2008, 350, 144-153. [CrossRef]

2. Liu, R.; Dong, G.; Xu, F.; Wang, X.; He, M. Spatial-temporal characteristics of phosphorus in non-point source pollution with grid-based export coefficient model and geographical information system. Water Sci. Technol. 2015, 71, 1709-1717. [CrossRef] [PubMed]

3. Xu, F.; Dong, G.; Wang, Q.; Liu, L.; Yu, W.; Men, C.; Liu, R. Impacts of DEM uncertainties on critical source areas identification for non-point source pollution control based on SWAT model. J. Hydrol. 2016, 540, 355-367. [CrossRef]

4. Kong, Y.; Zhu, L.; Lv, M.; Xu, X.; Qi, H. Research advances in water environment remediation and wastewater treatment based on three dimensional fluorescence spectroscopy technology. Ecol. Environ. Sci. 2012, 7, 1647-1654.

5. Kourakos, G.; Harter, T. Parallel simulation of groundwater non-point source pollution using algebraic multigrid preconditioners. Comput. Geosci. 2014, 18, 851-867. [CrossRef]

6. Liu, R.; Xu, F.; Liu, Y.; Wang, J.; Yu, W. Spatio-temporal characteristics of livestock and their effects on pollution in China based on geographic information system. Environ. Sci. Pollut. Res. 2016, 23, 14183-14195. [CrossRef]

7. Liu, R.; Zhang, P.; Wang, X.; Wang, J.; Yu, W.; Shen, Z. Cost-effectiveness and cost-benefit analysis of BMPs in controlling agricultural nonpoint source pollution in China based on the SWAT model. Environ. Monit. Assess. 2014, 186, 9011-9022. [CrossRef]

8. Li, W.; Cheng, X.; Zheng, Y.; Lai, C.; Sample, D.J.; Zhu, D.; Wang, Z. Response of non-point source pollution to landscape pattern: Case study in mountain-rural region, China. Environ. Sci. Pollut. Res. 2021, 28, 16602-16615. [CrossRef]

9. Liu, R.; Zhang, P.; Wang, X.; Chen, Y.; Shen, Z. Assessment of effects of best management practices on agricultural non-point source pollution in Xiangxi River watershed. Agric. Water Manag. 2013, 117, 9-18. [CrossRef]

10. Lam, Q.; Schmalz, B.; Fohrer, N. Modelling point and diffuse source pollution of nitrate in a rural lowland catchment using the SWAT model. Agric. Water Manag. 2010, 97, 317-325. [CrossRef]

11. Ongley, E.D.; Zhang, X.; Yu, T. Current status of agricultural and rural non-point source Pollution assessment in China. Environ. Pollut. 2010, 158, 1159-1168. [CrossRef] 
12. Ma, X.; Li, Y.; Li, B.; Han, W.; Liu, D.; Liu, X. Evaluation of nitrogen and phosphorus loads from agricultural nonpoint source in relation to water quality in Three Gorges Reservoir Area, China. Desalin. Water Treat. 2015, 57, 1-18. [CrossRef]

13. Liu, C.; Qian, W.; Zheng, B.; Yu, J.; Liu, Y. Spatial distribution of livestock \& poultry farming and its pollutants in Poyang Lake watershed. In Proceedings of the 2011 International Conference on Electrical and Control Engineering, Institute of Electrical and Electronics Engineers (IEEE), Yichang, China, 16-18 September 2011; pp. 5455-5458.

14. Sun, C.; Wu, H. Assessment of pollution from livestock and poultry breeding in China. Int. J. Environ. Stud. 2013, 70, 232-240. [CrossRef]

15. Zhu, L.A.; Wang, J.Z.; Yao, Y. Non-point Sources Pollution from Livestock and Poultry and Ecological Control. Bull. Soil Water Conserv. 2005, 40-43.

16. Wu, L.; Long, T.-Y.; Liu, X.; Guo, J.-S. Impacts of climate and land-use changes on the migration of non-point source nitrogen and phosphorus during rainfall-runoff in the Jialing River Watershed, China. J. Hydrol. 2012, 475, 26-41. [CrossRef]

17. Grosso, G.; Estruch, R. Nut consumption and age-related disease. Maturitas 2016, 84, 11-16. [CrossRef]

18. Capelli, L.; Sironi, S.; Del Rosso, R.; Guillot, J.-M. Measuring odours in the environment vs. dispersion modelling: A review. Atmos. Environ. 2013, 79, 731-743. [CrossRef]

19. Lentz, R.D.; Lehrsch, G.A. Mineral Fertilizer and Manure Effects on Leached Inorganic Nitrogen, Nitrate Isotopic Composition, Phosphorus, and Dissolved Organic Carbon under Furrow Irrigation. J. Environ. Qual. 2018, 47, 287-296. [CrossRef]

20. Wang, J.; Wang, D.; Zhang, G.; Wang, Y.; Wang, C.; Teng, Y.; Christie, P. Nitrogen and phosphorus leaching losses from intensively managed paddy fields with straw retention. Agric. Water Manag. 2014, 141, 66-73. [CrossRef]

21. Wing, S.; Horton, R.A.; Marshall, S.W.; Thu, K.; Tajik, M.; Schinasi, L.; Schiffman, S.S. Air Pollution and Odor in Communities Near Industrial Swine Operations. Environ. Health Perspect. 2008, 116, 1362-1368. [CrossRef]

22. Lee, S.C.; Park, I.H.; Lee, J.I.; Kim, H.M.; Ha, S.R. Application of SWMM for evaluating NPS reduction performance of BMPs. Desalin. Water Treat. 2010, 19, 173-183. [CrossRef]

23. Qiu, J.; Shen, Z.; Chen, L.; Xie, H.; Sun, C.; Huang, Q. The Stakeholder Preference for Best Management Practices in the Three Gorges Reservoir Region. Environ. Manag. 2014, 54, 1163-1174. [CrossRef]

24. Ma, B.; Guan, R.; Liu, L.; Huang, Z.; Qi, S.; Xi, Z.; Zhao, Y.; Song, S.; Yang, H. Nitrogen Loss in Vegetable Field under the Simulated Rainfall Experiments in Hebei, China. Water 2021, 13, 552. [CrossRef]

25. Yang, Q.; Benoy, G.A.; Chow, T.L.; Daigle, J.L.; Bourque, C.P.A.; Meng, F.R. Using the Soil and Water Assessment Tool to Estimate Achievable Water Quality Targets through Implementation of Beneficial Management Practices in an Agricultural Watershed. J. Environ. Qual. 2012, 41, 64. [CrossRef] [PubMed]

26. Ashworth, A.J.; Moore, P.A.; Pote, D.H.; Owens, P.R.; Martin, J.W.; Anderson, K.R. Conservation management practices reduce non-point source pollution from grazed pastures. Heliyon 2021, 7, e06238. [CrossRef] [PubMed]

27. Zhong, H.; Qing, P.; Hu, W. Farmers' willingness to participate in best management practices in Kentucky. J. Environ. Plan. Manag. 2015, 59, 1-25. [CrossRef]

28. Palm-Forster, L.; Swinton, S.; Shupp, R. Farmer preferences for conservation incentives that promote voluntary phosphorus abatement in agricultural watersheds. J. Soil Water Conserv. 2017, 72, 493-505. [CrossRef]

29. Panagopoulos, Y.; Makropoulos, C.; Mimikou, M. Reducing surface water pollution through the assessment of the costeffectiveness of BMPs at different spatial scales. J. Environ. Manag. 2011, 92, 2823-2835. [CrossRef]

30. Rousseau, A.N.; Savary, S.; Hallema, D.W.; Gumiere, S.J.; Foulon, É. Modeling the effects of agricultural BMPs on sediments, nutrients, and water quality of the Beaurivage River watershed (Quebec, Canada). Can. Water Resour. J. Rev. Can. des Ressources Hydriques 2013, 38, 99-120. [CrossRef]

31. Gassman, P.W.; Osei, E.; Saleh, A.; Hauck, L.M. Application of an Environmental and Economic Modeling System for Watershed Assessments. JAWRA J. Am. Water Resour. Assoc. 2002, 38, 423-438. [CrossRef]

32. Saleh, A.; Osei, E.; Gassman, P.W.; Hauck, L.M. Application of the Comprehensive Economic and Environmental Optimization Tool (CEEOT) for Evaluating BMPs. Proc. Water Environ. Fed. 2005, 2005, 344-374. [CrossRef]

33. Gassman, P.; Osei, E.; Saleh, A.; Rodecap, J.; Norvell, S.; Williams, J. Alternative practices for sediment and nutrient loss control on livestock farms in northeast Iowa. Agric. Ecosyst. Environ. 2006, 117, 135-144. [CrossRef]

34. Osei, E.; Gassman, P.W.; Hauck, L.M.; Jones, R.; Beran, L.; Dyke, P.T.; Goss, D.W.; Flowers, J.D.; McFarland, A.M.S.; Saleh, A. Environmental benefits and economic costs of manure incorporation on dairy waste application fields. J. Environ. Manag. 2003, 68, 1-11. [CrossRef]

35. Osei, E.; Du, B.; Bekele, A.; Hauck, L.; Saleh, A.; Tanter, A. Impacts of Alternative Manure Application Rates on Texas Animal Feeding Operations: A Macro Level Analysis. JAWRA J. Am. Water Resour. Assoc. 2008, 44, 562-576. [CrossRef]

36. Keplinger, K. The Economics of Total Maximum Daily Loads; Social Science Electronic Publishing: Rochester, NY, USA, 2003; Volume 43, pp. 1057-1091.

37. Wang, J.; Xia, Y.; Cheng, Q.X.; Fan, X.P.; Wu, M.Q.; Zhang, F.L.; Liu, D.B.; Zhang, J.M. Situation of Agricultural Non-point Source Pollution of the Xiangxi Brook Watershed in Xingshan County. Hubei Agric. Sci. 2014, 53, 5724-5730.

38. Cai, J.Z.; Fan, X.P.; Huang, M.; Liu, D.B.; Gan, X.Z.; Wang, L.N. Sources Analysis of Agricultural Non-point Source Pollution in the Three Gorges Reservoir Area of Hubei Province, China. J. Agro-Environ. Sci. 2012, 31, 1421-1430.

39. Liu, R.; Wang, Q.; Xu, F.; Men, C.; Guo, L. Impacts of manure application on SWAT model outputs in the Xiangxi River watershed. J. Hydrol. 2017, 555, 479-488. [CrossRef] 
40. Wang, Y.; Jiang, R.; Xie, J.; Zhao, Y.; Yan, D.; Yang, S. Soil and Water Assessment Tool (SWAT) Model: A Systemic Review. J. Coast. Res. 2019, 93, 22-30. [CrossRef]

41. Srinivasan, R.; Arnold, J.G.; Jones, C.A. Hydrologic Modelling of the United States with the Soil and Water Assessment Tool. Int. J. Water Resour. Dev. 1998, 14, 315-325. [CrossRef]

42. Chen, M.; Cui, Y.; Gassman, P.; Srinivasan, R. Effect of Watershed Delineation and Climate Datasets Density on Runoff Predictions for the Upper Mississippi River Basin Using SWAT within HAWQS. Water 2021, 13, 422. [CrossRef]

43. Steglich, E.; Williams, J. Agricultural Policy/Environmental eXtender Model. In User's Manual; BRC Report No. 2008-16; Texas A\&M Blackland Research Center: Temple, TX, USA, 2008.

44. Gassman, P.W.; Williams, J.R.; Wang, X.; Saleh, A.; Osei, E.; Hauck, L.M.; Izaurralde, R.C.; Flowers, J.D. Invited Review Article: The Agricultural Policy/Environmental eXtender (APEX) Model: An Emerging Tool for Landscape and Watershed Environmental Analyses. Trans. ASABE 2010, 53, 711-740. [CrossRef]

45. Tuppad, P.; Winchell, M.F.; Wang, X.; Srinivasan, R.; Williams, J.R. ArcAPEX: ArcGIS interface for Agricultural Policy Environmental eXtender (APEX) hydrology/water quality model. Int. Agric. Eng. J. 2009, 18, 59-71.

46. Zhao, J.; Chu, Q.; Shang, M.; Meki, M.N.; Norelli, N.; Jiang, Y.; Yang, Y.; Zang, H.; Zeng, Z.; Jeong, J. Agricultural Policy Environmental eXtender (APEX) Simulation of Spring Peanut Management in the North China Plain. Agronomy $2019,9,443$. [CrossRef]

47. Bolan, N.; Adriano, D.; Mahimairaja, S. Distribution and Bioavailability of Trace Elements in Livestock and Poultry Manure By-Products. Crit. Rev. Environ. Sci. Technol. 2004, 34, 291-338. [CrossRef]

48. Kovacic, D.A.; David, M.B.; Gentry, L.E.; Starks, K.M.; Cooke, R.A. Effectiveness of Constructed Wetlands in Reducing Nitrogen and Phosphorus Export from Agricultural Tile Drainage. J. Environ. Qual. 2000, 29, 1262-1274. [CrossRef]

49. Gregg, M.A.; Crawford, J.A.; Drut, M.S.; Delong, A.K. Vegetational Cover and Predation of Sage Grouse Nests in Oregon. J. Wildl. Manag. 1994, 58, 162. [CrossRef]

50. Brouwer, R.; Schaafsma, M. Modelling risk adaptation and mitigation behaviour under different climate change scenarios. Clim Change 2013, 117, 11-29. [CrossRef]

51. Lee, K.; Kim, H.; Pak, G.; Jang, S.; Kim, L.; Yoo, C.; Yun, Z.; Yoon, J. Cost-effectiveness analysis of stormwater best management practices (BMPs) in urban watersheds. Desalination Water Treat. 2010, 19, 92-96. [CrossRef]

52. Behera, P.K.; Teegavarapu, R.S.V. Optimization of a Stormwater Quality Management Pond System. Water Resour. Manag. 2014, 29, 1083-1095. [CrossRef]

53. Heatwole, C.D.; Bottcher, A.B.; Baldwin, L.B. Modeling Cost-effectiveness of Agricultural Nonpoint Pollution Abatement Programs on Two Florida Basins. JAWRA J. Am. Water Resour. Assoc. 1987, 23, 127-131. [CrossRef]

54. Geng, R.; Wang, X.; Sharpley, A.N.; Meng, F. Spatially-Distributed Cost-Effectiveness Analysis Framework to Control Phosphorus from Agricultural Diffuse Pollution. PLoS ONE 2015, 10, e0130607. [CrossRef] [PubMed]

55. Liu, J.; Liu, Q.; Zhao, C. Service Based Design Solutions-A Case of Migrant Workers' Affective Links with Their Families in Rural Areas of China. In Cross-Cultural Design. Methods, Practice, and Case Studies. CCD 2013. Lecture Notes in Computer Science; Rau, P.L.P., Ed.; Springer: Berlin/Heidelberg, Germany, 2013; Volume 8023. [CrossRef]

56. Zhou, Q.; Zeng, Z.; Nie, Z. Investigation on Women Staying at Home in Rural Areas-An Investigation from Chongqing Municipality. J. China Womens Univ. 2007, 63-66.

57. Li, F.; Cheng, S.; Yu, H.; Yang, D. Waste from livestock and poultry breeding and its potential assessment of biogas energy in rural China. J. Clean. Prod. 2016, 126, 451-460. [CrossRef]

58. AbdulHameed, M.F.; Habib, I.; Al-Azizz, S.A.; Robertson, I. Knowledge, Awareness and Practices Regarding Cystic Echinococcosis among Livestock Farmers in Basrah Province, Iraq. Vet. Sci. 2018, 5, 17. [CrossRef] [PubMed]

59. Conner, D.; Miller, J.; Zia, A.; Wang, Q.; Darby, H. Conjoint Analysis of Farmers' Response to Conservation Incentives. Sustainability 2016, 8, 684. [CrossRef]

60. Thompson, A.W.; Reimer, A.; Prokopy, L.S. Farmers' views of the environment: The influence of competing attitude frames on landscape conservation efforts. Agric. Hum. Values 2014, 32, 385-399. [CrossRef]

61. Chughtai, F.; Zayed, T. Infrastructure condition prediction models for sustainable sewer pipelines. J. Perform. Constr. Facil. 2008, 22, 333-341. [CrossRef]

62. Tian, Y.; Huang, Z.; Xiao, W. Reductions in non-point source pollution through different management practices for an agricultural watershed in the Three Gorges Reservoir Area. J. Environ. Sci. 2010, 22, 184-191. [CrossRef]

63. Niu, L.-A.; Hao, J.-M.; Zhang, B.-Z.; Niu, X.-S. Influences of Long-Term Fertilizer and Tillage Management on Soil Fertility of the North China Plain. Pedosphere 2011, 21, 813-820. [CrossRef]

64. Wright, M.J.; Davison, K.L. Nitrate Accumulation in Crops and Nitrate Poisoning in Animals. Adv. Agron. 1964, 16, 197-247. [CrossRef]

65. Raja, S.; Cheema, H.M.N.; Babar, S.; Khan, A.A.; Murtaza, G.; Aslam, U. Socio-economic background of wastewater irrigation and bioaccumulation of heavy metals in crops and vegetables. Agric. Water Manag. 2015, 158, 26-34. [CrossRef]

66. Liu, Y.D.; Xu, J.X.; Lu, J.H.; Zhao, P. Non-Point Source Nitrogen and Phosphorus Pollution Simulation and Irrigation Mode Optimization of the North Canal Basin. Water Sav. Irrig. 2011, 49, 479-486.

67. Arabi, M.; Govindaraju, R.S.; Hantush, M.M. Cost-effective allocation of watershed management practices using a genetic algorithm. Water Resour. Res. 2006, 42, 2405-2411. [CrossRef] 
68. Qiu, J.; Shen, Z.; Huang, M.; Zhang, X. Exploring effective best management practices in the Miyun reservoir watershed, China. Ecol. Eng. 2018, 123, 30-42. [CrossRef]

69. Zhang, X.; Srinivasan, R.; Debele, B.; Hao, F. Runoff simulation of the headwaters of the Yellow River using the SWAT model with three snowmelt algorithms. J. Am. Water Resour. Assoc. 2008, 44, 48-61. [CrossRef]

70. Nepal, S.; Flügel, W.A.; Shrestha, A.B. Upstream-downstream linkages of hydrological processes in the Himalayan region. Ecol. Process. 2014, 3, 19. [CrossRef]

71. Vigiak, O.; Newham, L.; Whitford, J.; Roberts, A.; Rattray, D.; Melland, A. Integrating farming systems and landscape processes to assess management impacts on suspended sediment loads. Environ. Model. Softw. 2011, 26, 144-162. [CrossRef]

72. Mohiuddin, K.M.; Otomo, K.; Ogawa, Y.; Shikazono, N. Seasonal and spatial distribution of trace elements in the water and sediments of the Tsurumi River in Japan. Environ. Monit. Assess. 2012, 184, 265-279. [CrossRef]

73. Desai, A.; Minton, C.; Coyne, K. Coordinated Stakeholder Implementation of Multiple TMDLs in Ventura County, California. Proc. Water Environ. Fed. 2009, 2009, 499-519. [CrossRef]

74. Hassanzadeh, E.; Strickert, G.; Morales-Marin, L.; Noble, B.; Baulch, H.; Shupena-Soulodre, E.; Lindenschmidt, K.-E. A framework for engaging stakeholders in water quality modeling and management: Application to the Qu'Appelle River Basin, Canada. J. Environ. Manag. 2019, 231, 1117-1126. [CrossRef]

75. Ansah, Y.B.; Frimpong, E.A. Impact of the adoption of BMPs on social welfare: A case study of commercial floating feeds for pond culture of tilapia in Ghana. Cogent Food Agric. 2015, 1, 1. [CrossRef]

76. An, N.; Fan, M.; Zhang, F.; Christie, P.; Yang, J.; Huang, J.; Guo, S.; Shi, X.; Tang, Q.; Peng, J.; et al. Exploiting Co-Benefits of Increased Rice Production and Reduced Greenhouse Gas Emission through Optimized Crop and Soil Management. PLoS ONE 2015, 10, e0140023. [CrossRef]

77. Carolan, M.S. Barriers to the Adoption of Sustainable Agriculture on Rented Land: An Examination of Contesting Social Fields* Rural. Sociol. 2005, 70, 387-413. [CrossRef]

78. Qi, Z.D.; Kang, G.L.; Wu, X.J.; Sun, Y.T.; Wang, Y.Q. Multi-Objective Optimization for Selecting and Siting the Cost-Effective BMPs by Coupling Revised GWLF Model and NSGAII Algorithm. Water 2020, 12, 235. [CrossRef]

79. Geng, R.Z.; Sharpley, A.N. A novel spatial optimization model for achieve the trad-offs placement of best management practices for agricultural non-point source pollution control at multi-spatial scales. J. Clean. Prod. 2019, 234, 1023-1032. [CrossRef]

80. Rabotyagov, S.S.; Jha, M.; Campbell, T.D. Nonpoint-Source Pollution Reduction for an Iowa Watershed: An Application of Evolutionary Algorithms. Can. J. Agric. Econ. Can. d'Agroeconomie 2010, 58, 411-431. [CrossRef]

81. Du, Y.; Wang, X.; Zhang, L.; Feger, K.-H.; Popp, J.; Sharpley, A. Multi-stakeholders' preference for best management practices based on environmental awareness. J. Clean. Prod. 2019, 236, 236. [CrossRef] 